RANKA GAŠIĆ, viši naučni saradnik

Institut za savremenu istoriju

Beograd, Trg Nikole Pašića 11

UDK 614.2(497.11)(091)

\title{
OSNIVANJE GRADSKE BOLNICE U BEOGRADU 1935.*
}

\begin{abstract}
APSTRAKT: U članku se razmatra osnivanje i gradnja Gradske bolnice u Beogradu (danas: KBC Zvezdara), sredstvima Fonda Zadužbine Nikole Spasića i prvi period njenog rada (do 1941), kao prve moderne gradske zdravstvene ustanove.
\end{abstract}

Ključne reči: istorija Beograda, istorija medicine, Gradska bolnica u Beogradu, Bulbuder, Zvezdara

Beograd je posle 1918. godine doživeo veliki priliv stanovništva sa teritorije cele Kraljevine SHS. Prema zvaničnim statistikama, stanovništvo se za prvih pet godina posle rata uvećalo gotovo četiri puta, što predstavlja najveći porast $u$ dosadašnjoj istoriji koji se odigrao u tako kratkom vremenu. Ta činjenica je sama po sebi povećavala rizik za pojavu bolesti i epidemija, koji je bio pojačan i time što je grad tokom rata bio razoren, a ionako slaba gradska infrastruktura (vodovod i kanalizacija, osvetljenje i dr.) bila je izvan funkcije. U takvim uslovima bilo je gotovo nemoguće praktikovati preventivnu medicinu, koja je od suštinskog značaja za zdravlje svake ljudske zajednice. Samo lečenje takođe je bilo povezano sa velikim materijalnim troškovima. Privatnih lekara bilo je premalo, a s druge strane, postojalo je previše stanovništva koje nije moglo da plaća njihove usluge. Beograd se našao pred teškim problemom reforme zdravstva i borbe protiv moći „tradicionalnog" lečenja, to jest nadrilekarstva i magije. ${ }^{1}$ Tako je posle Prvog svetskog rata prvi put ustanovljeno Ministarstvo socijalne politike i narodnog zdravlja i država je time preuzela na centralnom nivou brigu o zdravstvenom stanju nacije. Međutim, državne zdravstvene ustanove nisu mogle

* Rad je deo projekta Srpsko društvo u jugoslovenskoj državi u 20. veku: između demokratije i diktature (broj 177016), koji finansira Ministarstvo prosvete i nauke Republike Srbije.

${ }^{1}$ Tihomir Simić, Nekoliko važnijih sanitetsko-higijenskih problema Beogradske opštine, Beogradske opštinske novine (dalje: BON), 6-7, 1936, 562-565, 564. 
da pokriju potrebe Beograda kao velikog centra tako da je Beogradska opština morala da osniva razne zdravstvene i higijenske ustanove, koliko su to njena sredstva dozvoljavala. Sredinom tridesetih godina 20 . veka jedna stručna komisija dala je izveštaj o stanju zdravstvenih ustanova u gradu, koji pokazuje pravo stanje zdravstvene službe: konstatovano je da je za prethodnih 15 godina od gradskih zdravstvenih ustanova podignut samo dezinfekcioni zavod, a da su prostorije za hitnu pomoć bile smeštene na mestima gde su se ranije nalazile tzv. čistačke kolone, dok je prevoz bolesnika obavljan u tako lošim uslovima da je mogao ozbiljno pogoršati stanje pacijenta. Higijena instrumenata takođe je bila jako loša. Pri tom, postojeće zdravstvene ustanove nisu bile koncentrisane na jednom prostoru već razbacane po čitavom gradu. ${ }^{2}$ Naravno, jedan od osnovnih razloga teškog zdravstvenog stanja većine beogradskog stanovništva bio je nedostatak stambenog prostora. Pomenuta komisija je među ostalim merama navela i pitanje jeftinih i higijenskih stanova, kao osnovno pitanje preventivne medicine, uviđajući ispravno da je za to neophodna državna intervencija u građevinskoj politici. Razumljivo, taj problem je bio daleko složeniji i u tesnoj vezi ne samo sa građevinskom politikom već i sa ukupnim ekonomskim stanjem u zemlji. ${ }^{3}$

Istorijat zdravstvenih ustanova u Beogradu pre osnivanja gradske bolnice ukazuje na to da se na ovom planu ipak nešto preduzimalo, prema mogućnostima. Pre Prvog svetskog rata sanitetsko odeljenje opštine, osnovano 1894, imalo je samo pet lekara. Od zdravstvenih ustanova opština je imala samo Centralnu ambulantu (koja se nalazila kod kafane „London“). Tu su postojali samo lekari opšte medicine i bolničari koji su ukazivali prvu pomoć. Posle rata porasla je uloga opštine u zdravstvenoj delatnosti, a posebno u lečenju mnogobrojne gradske sirotinje. Ukazala se hitna potreba za dostupnom, efikasnom i jeftinom medicinskom negom. Pri Centralnoj ambulanti uvedena je služba hitnog prevoza povređenih i zarazno obolelih. Do 1920. ova služba je imala samo jedna kola, a od tada je dobila fijaker i dva bolesnička autobusa, od računa reparacija. Od 1923. ona je organizovana kao Stanica za spasavanje i hitnu pomoć. Sanitetsko odeljenje je reorganizovano 1926, i u njegov sastav je ušla ova Stanica za spasavanje, sa pojačanim osobljem i prevozom. Godine 1928. povećan je broj ambulanata na periferiji i izvršena podela lekarske službe po rejonima, čime je odvojena preventivna od kurativne medicine. Sanitetsko odeljenje je tek 1929. organizo-

\footnotetext{
${ }^{2}$ T. Simić, $n$. d., 565 .

3 T. Simić, n. d., 565; Tihomir Simić, Sanitetsko higijenski problemi Beograda II, BON, br. 10-11, 1936, 694-703, 695. O problemu stanovanja siromašnih Beograđana između dva rata videti: Zlata Vuksanović Macura, Uslovi i oblici stanovanja siromašnih žitelja Beograda između dva svetska rata (1919-1941), magistarski rad u rukopisu, Univerzitet u Beogradu, Arhitektonski fakultet, Beograd 2010.
} 
vano u četiri odseka (za školsku higijenu, javnu higijenu, sanitarne ustanove i veterinu). Po Statutu Opštine grada Beograda iz 1929. formirano je Odeljenje za socijalno i zdravstveno staranje, sa posebnim Odsekom za lečenje i sanitarne ustanove. Opština je otvorila tri periferne ambulante - $\mathrm{u} \mathrm{Bu}-$ levaru vojvode Mišića, u Bulevaru oslobođenja i u Bulevaru kralja Aleksandra. Te ambulante bile su smeštene u napuštenim trošarinskim stanicama, u veoma lošim uslovima. ${ }^{4}$

Do početka Drugog svetskog rata, brojno stanje i kvalitet zdravstvenih institucija Beograda bitno su se popravili, ali se ne može reći da je i tada situacija bila sasvim zadovoljavajuća, s obzirom na siromaštvo većine stanovnika grada. Tokom tridesetih godina Beograd je već imao nekoliko značajnih medicinskih ustanova: Sanatorijum Vračar (dvospratna zgrada u Birčaninovoj ulici), Gradska poliklinika, ${ }^{5}$ Hirurška bolnica u ulici Prote Mateje, Bolnica za ženske i dečje bolesti na Dedinju, ${ }^{6}$ porodilište u Sredačkoj ulici (1930), antituberkulozni dispanzer u Bulevaru kralja Aleksandra, ${ }^{7}$ Dom dečije zaštite (za napuštenu decu, podignut 1935. na opštinskom zemljištu „Pionir"), Gradska bolnica (podignuta krajem 1935, iz Fonda Zadužbine Nikole Spasića), zgrada za lečenje trgovačke omladine u Zvečanskoj (podigao Nikola Kiki, 1937. godine), Gradski dom za nezbrinutu decu u Zvečanskoj (podignut 1938, iz Fonda Zadužbine Nikole Spasića), Ambulanta za kožne i venerične bolesti u ulici Džordža Vašingtona (1937). ${ }^{8}$

Najznačajnija među opštinskim zdravstvenim ustanovama ovog perioda bila je Gradska bolnica, podignuta 1935, osnovana sredstvima Fonda Nikole Spasića, koja je nosila i ime darodavca. Nikola Spasić je bio veoma imućan beogradski trgovac. O njegovom poreklu zna se da se porodica doselila u Beograd 1807. iz južne Srbije, okoline Uroševca ili Štimlja. Nikola je stekao obrazovanje u beogradskom Liceju, a 1865. otvorio je opančarsku

\footnotetext{
${ }^{4}$ Zdravlje i socijalna pomoć u Beogradu za 1935 i 1936 godinu, Beograd 1937, 204-210, 204-205.

${ }^{5}$ Dr Vladimir Stanojević, Zdravstvena služba od 1918 do danas, Istorija Beograda, 3, Beograd 1974, 487-494, 492-493. - Poliklinika je prvobitno radila u nehigijenskim uslovima, a 1936. premeštena je na pristupačno mesto, u zgradu Sanatorijuma Živković u Kneginje Perside 58 (danas zgrada Studentske poliklinike u Krunskoj 57). Tada je dobila specijalistička odeljenja, dežurne lekare i davala je besplatne usluge siromašnima. Odatle su svi pacijenti upućivani u Opštu državnu ili Gradsku bolnicu. (Zdravlje i socijalna pomoć..., 246 i dalje).

${ }^{6}$ Plac za ovu zgradu poklonio je opštini Đorđe Vajfert, a bonicu je osnovalo Društvo beogradskih žena lekara (dr V. Stanojević, $n$. d., 492).

${ }^{7}$ Gradski antituberkulozni dispanzer je prvi put otvoren 1932. i počeo je prikupljati podatke o tuberkulozi u Beogradu. Posle toga, otvorena su još tri savetovališta za tuberkulozu. Dispanzer je 1935. konačno, na zauzimanje gradonačelnika Vlade Ilića, premešten u adaptiranu i modernu zgradu u Bulevaru kralja Aleksandra 237, pošto se prethodno tri puta selio (Zdravlje i socijalna pomoć..., 252).

${ }^{8}$ Dr V. Stanojević, n. d., 487-494.
} 
radnju. Prosperirao je tokom šezdesetih i sedamdesetih godina 19. veka, kada je sagradio kuću u Knez Mihailovoj (danas ulica na uglu Knez Mihailove, pored njegove zgrade, nosi njegovo ime). Tokom srpsko-turskih ratova 1875-1878. bio je vojni liferant i tada je stekao najveći deo imovine. Otkupio je deo državnog duga, bio predsednik Beogradske berze i Prometne banke i član Upravnog odbora Narodne banke Srbije. Pomagao je pokrete za oslobođenje južne Srbije, posebno tokom Balkanskih ratova. Tada je osnovao pomoćnu bolnicu za lečenje ranjenika sa 50 ležajeva, u zgradi Uprave monopola, u čemu je posebno bila aktivna njegova supruga. Umro je na $\mathrm{Kr}$ fu tokom Prvog svetskog rata, posle povlačenja sa vojskom preko Albanije. Supruga ga je 1923. sahranila na Topčiderskom groblju, u crkvi koja je bila njegova zadužbina. ${ }^{9}$ Nikola Spasić se aktivno bavio humanitarnim radom: pored bolnice za vojnike iz 1912, još 1908. osnovao je zgradu za đačko sklonište u dvorištu Palilulske osnovne škole, gde je pomagao siromašnu školsku decu. Krajem 1912. sastavio je testament, kojim je svoju imovinu zaveštao u vrlo raznovrsne svrhe, što ga posebno izdvaja među srpskim zadužbinarima tog vremena. Njegova Zadužbina je i dalje brinula o deci u đačkom skloništu. Jednu sumu je zaveštao za osnivanje Doma za iznemogle i sirote srpske građane u Knjaževcu (koji je podignut sredinom 30-ih godina), dok je najveći deo novca namenio za „privredne ciljeve“, da njegova Zadužbina prema nahođenju i potrebi o tome odlučuje. Svoju kuću na uglu Knez Mihailove i Vuka Karadžića ustupio je 1915. vojsci, kao Dom Srpskog narodnog invalidskog fonda „Sv. Đorđe“. Još 1903. na Topčiderskom groblju je podigao kapelu (u kojoj je kasnije sahranjen), i zaveštao da se za Crkvu Sv. Save kupi veliko zvono. ${ }^{10}$ Testamentom je bilo određeno da se u Srbiji podignu tri bolnice, i u te svrhe izdvojeno 350.000 dinara predratne Kraljevine Srbije radi podizanje bolnice u Beogradu, na opštinskom zemljištu i u njenom vlasništvu, za namenu koju „odrede saniteti“. Još 200.000 dinara bilo je namenjeno za dve bolnice $u$ unutrašnjosti zemlje i dom za stara lica. Od te sume osnovan je 1922. fond za zidanje bolnica u okviru Zadužbine. Fond je stalno rastao, jer su u njega unošeni svi prihodi od hartija od vrednosti i od renti. Kako je međutim vrednost dinara od 1919. stalno opadala dok su cene građevinskog materijala i nadnica rasle, suma koju je Spasić namenio za Gradsku bolnicu nije bila dovoljna za pokrivanje troškova zidanja i opremanja. Fondu je 1932. pridodat i prihod od kuće u Knez Mihailovoj 47, tako da je ukupan fond za bolnice narastao na 8,5 miliona dinara, od čega je 5.250 .000 bilo namenjeno Gradskoj bolnici u Beogradu. ${ }^{11}$

${ }^{9}$ Milan Andrejević, Stvarali su gradsku bolnicu 1936-2006. 70 godina rada KBC „Zvezdara“, Beograd 2007, 5-6.

${ }_{10}^{10}$ Privredni letopis Zadužbine Nikole Spasića, knj. 1, Beograd 1936, 125-136, 132-135.

${ }^{11}$ Gradska bolnica Beograd. 30 godina, Beograd 1976, 9. 
Tek je po donošenju gradskog statuta 1929. započela je akcija za zidanje opštinske bolnice. Krajem te godine, na predlog Sanitetskog odeljenja beogradske opštine, Zadužbina Nikole Spasića odlučila je da se sume predviđene za podizanje bolnice u Beogradu i onih u unutrašnjosti, kao i Doma za iznemogle i sirote srpske građane $u$ celini upotrebe za podizanje moderne bolnice u Beogradu, na zemljištu koje odredi opština. Ministarstvo prosvete je, međutim, 1932. odbilo da odobri ovu odluku, pošto nije bila u skladu sa voljom zaveštaoca. Tako je ponovo akcija bila obustavljena, zbog nedostatka sredstava. ${ }^{12}$ Pregovori odbora Zadužbine i opštine o podizanju bolnice nastavljeni su krajem oktobra 1932, kada je odlučeno da se traži od Suda OGB da u smislu tačke 14 testamenta N. Spasića ${ }^{13}$ izdejstvuje odobrenje Ministarstva socijalne politike i narodnog zdravlja za podizanje bolnice određene namene (koja će se naknadno odrediti), da se odredi zemljište (po mogućnosti blizu Opšte državne bolnice na Vračaru), izrade tehnički planovi koje će odobriti uprava Zadužbine i da se ne sme preći odobren kredit od 5.250.000 dinara, te da bolnica nosi ime Nikole Spasića. ${ }^{14}$

Beogradska opština je krajem 1932. imenovala stručnu komisiju koja će se baviti pitanjem podizanja bolnice sa sanitetske, tehničke i pravne strane, na čelu sa dr Ksenofonom Šahovićem. ${ }^{15}$ Šahović je, kao gradski odbornik i profesor Medicinskog fakulteta, bio određen da učestvuje u izradi elaborata. ${ }^{16}$ Tehnička direkcija opštine pripremila je tada planove za podizanje bolnice na opštinskom placu u Pasterovoj ulici, pored Doma staraca i starice i Medicinskog fakulteta, po kojima je trebalo podići tri paviljona. Međutim, predračun za ovu zgradu iznosio je mnogo više od sume koju je imala Zadužbina (30 miliona dinara). ${ }^{17}$ Zato je odlučeno da se podigne

${ }^{12}$ Zdravlje i socijalna pomoć... 204-210; Istorijski arhiv Beograda (dalje: IAB), fond Opštine grada Beograda (dalje: OGB), fascikla 2134, Zadužbina Nikole Spasića - Sudu OGB, 29. oktobar 1932.

${ }^{13}$ U tački 14 testamenta piše: „Izvršioci moga testamenta izdvojićedu iz moje pokretne imovine trista pedeset hiljada dinara. S tim novcem da se podigne bolnica na opštinskom zemljištu i za koju vrstu bolesti reknu saniteti i kad bude gotova ima se predati opštini Beogradskoj." Dalje, u tački 15, navedene su odredbe o drugim bolnicama van Beograda: „Pored ovoga, moja je želja da se izdvoji još dvesta hiljada dinara za podignuće još dve bolnice u vnutrenosti gde je najpotrebnije i za svaku će se utrošiti po 80000 dinara, a 40000 da se podigne jedan dom za sirotne i iznemogle srpske građane, podigao N Spasić." (IAB, fond OGB, fascikla 2134, Izvod iz testamenta N Spasića).

${ }^{14}$ IAB, fond OGB, fasc. 2134, Zadužbina Nikole Spasića - Sudu OGB, 29. oktobar 1932.

${ }^{15}$ IAB, fond OGB, fasc. 2134, Potpredsednik opštine - Sudu OGB, 5. oktobar 1932. - Dr Ksenofon Šahović (1898-1956), akademik i profesor Medicinskog fakulteta, član masonske lože, bio je osnivač prvog Onkološkog instituta u Beogradu (1940) i rodonačelnik onkologije u Beogradu. Godine 1970. osnovan je institut koji je dobio ime po njemu, objedinjavanjem Onkološkog instituta i Centralnog onkološkog dispanzera.

${ }^{16} \mathrm{IAB}$, fond OGB, fasc. 2134, rešenje Suda opštine beogradske, 30. novembar 1932.

${ }^{17}$ IAB, fond OGB, fasc. 2134, Tehnička direkcija - Sudu OGB, 25. novembar 1932. 
samo jedan paviljon. ${ }^{18}$ Kako su potrebe Beograda za medicinskim ustanovama bile daleko veće od mogućnosti, komisija je raspravljala o nameni buduće bolnice, ali i o mestu gde bi se ona nalazila. Dr Dimitrije Antić, profesor univerziteta, savetovao je opštinskom odboru da se bolnica nameni isključivo za lečenje tuberkuloze, koja je bila najveći zdravstveni problem Beograda u to vreme. Opština je od 1932. imala Antituberkulozni dispanzer, koji je kasnije i priključen Gradskog bolnici, pa ovaj predlog nije prihvaćen i rešeno je da se podigne bolnica opšteg tipa, za sve bolesti osim infektivnih. Po pitanju lokacije, pojavila su se dva predloga - da se podigne u okolini Crvenog krsta ili da se otkupi zgrada Sanatorijuma sv. Đorđe u Stiškoj ulici. ${ }^{19}$

Tehnička direkcija OGB je upravi Zadužbine dala na pregled dokumentaciju 4. aprila 1933, a već dva dana kasnije 6. aprila na sastanku odbora Zadužbine odlučeno je da se primi projekat za izradu jednog paviljona sa predračunom i raspiše licitacija za izvođača. U opštinski budžet 1933. uneta su potrebna sredstva za troškove bolničkog lečenja siromašnih, što je bio osnovni preduslov da jedna ovakva bolnica normalno funkcioniše. ${ }^{20} \mathrm{Na}$ sednici opštinskog odbora 13. aprila 1933. rešeno je da se započne sa podizanjem bolnice iz Fonda Zadužbine Nikole Spasića i da opština u te svrhe ustupi svoje zemljište između ulica Sv. Nikole i Dimitrija Tucovića, u kraju koji se tada zvao Bulbuder (danas deo Zvezdare) ${ }^{21} \mathrm{U}$ to vreme ovo je bila daleka periferija grada, bez saobraćaja i odgovarajuće infrastrukture, ali se kraj vrlo brzo naseljavao. Odbor Zadužbine u početku nije želeo da prihvati ponuđeni plac na Bulbuderskom potoku upravo iz ovih razloga. Bilo je i drugih predloga, na primer da bolnica bude na Tašmajdanu ili negde bliže centru i drugim postojećim bolnicama. Međutim, usvojen je predlog koji je detaljno proučila Tehnička direkcija opštine - da se nameni plac od oko $20.000 \mathrm{~m}^{2}$ na Bulbuderu, pored opštinskih stanova između ulica Sv. Nikole i Dimitrija Tucovića sa malom izmenom, da zgrada bolnice bude postavljena bliže ulici D. Tucovića, jer se u ulici Sv. Nikole, malo iznad bolnice, nalazila gradska ciglana. ${ }^{22}$ Opština se obavezala da će hitno izgraditi vodovod i kanalizaciju u okolini bolnice.

${ }^{18}$ IAB, fond OGB, fasc. 2134, Tehnička direkcija - Direkciji za socijalno i zdravstveno staranje, 16. decembar 1932.

${ }^{19}$ IAB, fond OGB, fasc. 2134, Zapisnik sa komisijskog sastanka na dan 31.12.1932.

${ }^{20}$ Zdravlje i socijalna pomoć....... 204-210.

${ }^{21}$ IAB, Zapisnici odbora opštine beogradske. Knjiga zapisnika odborskih odluka, knj. 1. 1933, inv. br. 67, zapisnik VII sednice od 13. aprila 1933.

22 IAB, Zapisnici odbora opštine beogradske. Knjiga zapisnika odborskih odluka, knj. 1. 1933, inv. br. 67, zapisnik VII sednice od 13. aprila 1933; IAB, fond OGB, fasc. 2134, Tehnička direkcija - Direkciji za socijalno i zdravstveno staranje, 17. februar 1933; IAB, fond OGB, fasc. 2134, Opšte odeljenje OGB - Odeljenju za socijalno i zdravstveno staranje; IAB, fond OGB, fascikla 2134, Zadužbina N. Spasića - Sudu OGB, 18. april 1933. 
Za projektanta bolničke zgrade određen je arh. Ignjat Popović, zaposlen u Tehničkoj direkciji opštine. ${ }^{23}$ Sredinom 1933. održana je licitacija za izvođača radova, na kojoj je posao dobilo preduzeće inžinjera Petra Stankovića i Dušana Đorđevića, ponudivši sumu za 29\% nižu od predviđene. ${ }^{24}$ Tako je ukupna izgradnja bolnice trebalo da košta 3,680.619 dinara. U izradi projekta učestvovali su kako tehnički tako i medicinski stručnjaci u opštini. Sa tehničke strane bila je projektovana i izvedena na tada najsavremeniji način, sa temeljima od armiranog i nabijenog betona, zidovima od opeke, sa armirano-betonskom konstrukcijom među spratovima. Predviđena je instalacija centralnog grejanja toplom vodom, lift za bolesnike, hranu i rublje, kanalizacija i vodovod, električne instalacije, prema tadašnjim propisima Uprave i Opštine grada. ${ }^{25}$

Centralni higijenski zavod i Ministarstvo socijalne politike i narodnog zdravlja uticali su na projekat sa medicinske strane. Prema zahtevu direktora Zavoda, usvojen je odgovarajući raspored prostorija prema polu bolesnika i vrsti bolesti, odvojene su kuhinjske prostorije sa zasebnim ulazom u suterenu i zasebnim odeljenjem za dezinfekciju sudova, predviđen je odgovarajući način sprovođenja pacijenata od ulaza do bolničkih kreveta, tako da se dezinfekcija veša vrši u suterenu uz uređaje za pranje. Predviđena je prirodna ventilacija, s tim da se naknadno ugradi veštačka sa propisanim intervalom promene vazduha na 15 minuta. Takođe je na traženje direktora Centralnog higijenskog zavoda, rešeno da kapela i prosektura budu izvan bolničke zgrade, da se naknadno projektuju kao zasebni paviljoni. U sporazumu sa Sanitetskim odeljenjem, odustalo se od izvođenja stanova za upravnika u zgradi bolnice i rešeno je da se za upravnika i ostalo osoblje adaptiraju stanovi u opštinskoj stambenoj zgradi u blizini bolnice. Tako je i treća etaža bila namenjena pacijentima. Na svakom spratu bio je prostor za

${ }^{23}$ IAB, fond OGB, fasc. 2134, rešenje Suda opštine beogradske od 18. avgusta 1933. - Arhitekta Ignjat Popović (1904-1973) bio je zaposlen u Tehničkoj direkciji Beogradske opštine 1929-1936, a radio je kao samostalni autor od 1936. do 1941. U međuratnom periodu projektovao je, osim Gradske bolnice i niza privatnih zgrada, još i Školu „na čistom vazduhu“ u Šumatovačkoj ulici (1931), Dom Udruženja studentkinja „Kraljica Marija“ u 27. marta (1932) i Dom Zanatsko- penzionog fonda u Kolarčevoj 4 (1936). Karijeru je završio kao profesor Građevinskog fakulteta u Beogradu (od 1951) - Leksikon neimara, Zoran Manević (red.), Beograd 2008, 327.

${ }^{24}$ Predračunska suma iznosila je 5.235.582,36 dinara. IAB, fond OGB, fasc. 2134, Tehnička direkcija - Sudu opštine beogradske, 18. juli 1933; IAB, fond OGB, fasc. 2134, Rešenje Suda od 22. jula 1933. da se raspiše licitacija sa rokom od 20 dana; IAB, fond OGB, fasc. 2134, rešenje Suda opštine beogradske od 18. avgusta 1933; IAB, fond OGB, fasc. 2134, Tehnička direkcija - Sudu OGB, 22. jun 1933.

${ }^{25}$ IAB, fond OGB, fasc. 2134, Tehnički opis zgrade nove opštinske bolnice Zadužbine N. Spasića, pregledano u Ministarstvu građevina 19. jula 1933; IAB, fond OGB, fasc. 2134, Tehnička direkcija - Sudu OGB, 22. jun 1933. 
ambulantu. ${ }^{26}$ Konačan projekat predviđao je jedan paviljon, sa podrumom, suterenom, prizemljem i tri etaže sa potkrovljem, i površinom u osnovi od $900 \mathrm{~m}^{2}$. Pošto ovaj kraj nije imao kanalizaciju, u početku je bilo predviđeno da se ona poveže sa biološkim jamama, dok se ne završi izrada bulbuderskog kolektora. ${ }^{27}$ Odobrenje Ministarstva građevina i građevinska dozvola stigli su krajem jula $1933 .{ }^{28} \mathrm{i}$ tako su krajem septembra iste godine konačno započeli radovi. Svečanost osvećenja kamena temeljca održana je 29. oktobra 1933. Pored zvaničnika opštine i crkve, na svečanosti su bili prisutni članovi Društva za ulepšavanje Bulbudera, pošto je otvaranje ovakve ustanove bilo od velikog značaja za komunalni napredak ovog veoma siromašnog kraja, koji do tada nije bio snabdeven ni osnovnim komunalnim potrebama a u higijenskom pogledu je bio veoma zapušten. ${ }^{29}$

Završetak radova na izgradnji bolnice bio je praćen problemima pravne i finansijske prirode, što je inače bio čest slučaj u međuratnom Beogradu. Zgrada je trebalo da bude gotova 1. jula 1934. Preduzimačima je u jednom trenutku priprećeno oduzimanjem posla. Krajem 1934. preduzeće je obavestilo nadzornog arhitektu da je posao završen i tražilo je kolaudaciju (prijem radova), a kao razlog za kašnjenje naveli su da drugo preduzeće radi instalaciju centralnog grejanja, što je znatno usporilo njihov rad. ${ }^{30}$ Ipak, u leto 1935. zgrada je konačno završena, i pored finansijskih problema. Podizanje dve sporedne zgrade opština je preuzela na sebe i zamolila Zadužbinu da joj preda preostali novac da sama završi posao, uključujući i unutrašnje uređenje i opremu. Tako je Zadužbina predala opštini 700.000 dinara. Ni ovde, međutim, nije bio kraj finansijskim izdacima. Pošto je bolnica svečano otvorena u septembru 1935, opština je ponovo u novembru iste godine tražila novac od Zadužbine Nikole Spasića za nabavku instrumenata i druge opreme. Zadužbina je odobrila dodatnih 180.000 dinara, pod uslovom da to bude poslednje potraživanje i da bolnica započne rad 1. decembra, sa 100 postelja. Na kraju, bolnica je koštala Zadužbinu ukupno

${ }^{26}$ IAB, fond OGB, fasc. 2134, Molba Ministarstvu socijalne politike i narodnog zdravlja upućena od strane opštine 20. aprila 1933; IAB, fond OGB, fasc. 2134, Centralni higijenski zavod - Ministarstvu socijalne politike i narodnog zdravlja, 23. maj 1933.

${ }^{27}$ IAB, fond OGB, fasc. 2134, Tehnička direkcija - Sudu OGB, 22. jun 1933.

${ }^{28}$ IAB, fond OGB, fasc. 2134, Odobrenje Ministarstva građevina od 27. jula 1933; IAB, fond OGB, fasc. 2134, građevinska dozvola izdata 24. jula 1933.

${ }^{29} \mathrm{Na}$ Bulbuderu je juče osvećen kamen temeljac opštinske bolnice, Politika, 30. oktobar 1933; Osvećenje kamena temeljca Opštinske bolnice na Bulbuderu, BON, 10-11, 1933, 694-695.

${ }^{30} \mathrm{IAB}$, fond OGB, fasc. 2134, Tehničko preduzeće inž P. Stankovića i D. S. Đorđevića - nadzornom arhitekti, 31. decembar 1934; IAB, fond OGB, fasc. 2134, Rešenje predsednika opštine od 22. januara 1935. kojim se određuju članovi kolaudirajuće komisije. 
5,284.177 dinara, umesto predratnih 350.000 koliko je bilo predviđeno testamentom. $^{31}$

Međutim, i na strani opštine pojavio se nepredviđen trošak. Opština je sa svim izabranim preduzimačima potpisivala tipski ugovor, po kojem je bilo predviđeno da izvođač snosi sve troškove opštinskih i državnih poreza i dažbina koji postoje na dan potpisivanja ugovora. Preduzeće P. Stankovića i D. S. Đorđevića obratilo se nadzornom arhitekti u julu 1935. sa zahtevom da im se vrati novac koji su morali da plate državi na ime novouvedene trošarine na cement, na šta preduzeće nije računalo kada je podnelo ponudu na licitaciji. Dakle, troškove ove trošarine trebalo bi da snosi vlasnik zgrade, tj. Zadužbina Nikole Spasića i Opština grada Beograda. ${ }^{32}$

Posle obimne prepiske između raznih direkcija i odeljenja opštine, Pravnički odbor je dao mišljenje da je preduzeće u pravu i da im se mora priznati višak u plaćenoj trošarini. ${ }^{33}$ Gradsko poglavarstvo je, shodno tome, donelo odluku da se preduzeću prizna plaćena trošarina na cement u iznosu od 100,893,48 dinara, i da to padne na teret opštinskog budžeta. ${ }^{34}$ Gradonačelnik Vlada Ilić pokušao je krajem juna 1936. da ovu sumu naplati od Zadužbine Nikole Spasića, tvrdeći da opština nema mogućnosti u budžetu za ovaj izdatak. ${ }^{35}$ Kako preduzeće nije bilo obeštećeno ni u narednih nekoliko meseci, njihov pravni zastupnik zapretio je u novembru iste godine Poglavarstvu grada Beograda tužbom. ${ }^{36}$ Isto takvo pismo od advokata je dobila i Zadužbina Nikole Spasića koja je, međutim, htela da trošak prebaci na teret opštine. Tražili su da „.. Gradsko poglavarstvo... ovu stvar raspravi sa preduzimačem i ne dopusti da se Zadužbina, sa kojom je Poglavarstvo taj posao potpuno likvidiralo, uvlači u jednu nepotrebnu parnicu“. S obzirom na to da je posao između Zadužbine i Opštine likvidiran, a sredstva namenjena za bolnicu potpuno iscrpljena, Zadužbina je krajem novembra 1936.

${ }^{31}$ Privredni letopis Zadužbine Nikole Spasića, knj. 2, Beograd 1937, 22-23.
${ }^{32}$ Državna trošarina na cement od 15 dinara na $100 \mathrm{~kg}$ uvedena je 2. novembra 1933, a 1. juna 1934. snižena je za potrošače na 7,5 din po $100 \mathrm{~kg}$ (IAB, fond OGB, fasc. 2134, Preduzeće P. Stankovića i D. S. Đorđevića - nadzornom arhitekti. 29. jul 1935).

${ }^{33}$ IAB, fond OGB, fasc. 2134, Prepiska između Tehničke direkcije, Pravničkog odbora, Arhitektonskog odseka, Opšteg odeljenja i Privredno-finansijske direkcije. Gradsko poglavarstvo - Opštem odeljenju, 18. oktobar 1935; IAB, fond OGB, fasc. 2134, Direktor Opšteg odeljenja - Privredno-finansijskom odeljenju, 18. april 1936.

${ }^{34} \mathrm{IAB}$, fond OGB, fasc. 2134, Gradsko poglavarstvo - Tehničkoj direkciji, 28. maj 1936; IAB, fond OGB, fasc. 2134, Gradsko poglavarstvo - Odseku za izradu i izvršenje budžeta, 23. februar 1937.

${ }^{35}$ IAB, fond OGB, fasc. 2134, Predsednik Opštine grada Beograda - upravi Zadužbine N Spasića, 27. jun 1936.

${ }^{36}$ IAB, fond OGB, fasc. 2134, Advokat Sveta Panajotović, pravni zastupnik preduzeća P. Stanković i Đorđević - gradonačelniku Vladi Iliću, 14. novembar 1936. 
zvanično donela odluku da ovu isplatu ne primi na sebe. ${ }^{37}$ Opština nije imala drugi izlaz nego da ovu sumu isplati preduzimačima, što je i učinjeno u martu $1937 .^{38}$

Ovaj slučaj je, inače, značajan pokazatelj nedovoljnog razgraničenja kompetencija i nejasnih svojinskih odnosa između države i Opštine grada Beograda. U pitanju je bila državna trošarina, dakle, pomenutu sumu nije naplatila opština već država, ali je preduzeće morala da obešteti upravo opština. Prema odluci Državnog saveta od 24. aprila 1934, na koju se u svom pismu pozvao advokat preduzimača (videti nap. 35), u sličnim slučajevima preduzimač je imao pravo na obeštećenje od strane države ili opštine, ali u ovom slučaju je opština, kao vlasnik bolnice, morala da snosi troškove državne trošarine.

Tako je 1. decembra 1935. konačno počela da radi jedna od danas najvažnijih zdravstvenih ustanova u Beogradu i Srbiji. Nagli razvoj doživela je tek posle Drugog svetskog rata, ali je u prvih pet godina rada (do 1941), napravila vrlo značajne korake $u$ kontekstu tadašnjeg nivoa zdravstvene zaštite i lečenja. Po komforu i uređenju bila je vrhunska ustanova za to vreme u Beogradu. U početku bolnica je imala samo 100 kreveta, a tadašnji kapaciteti dozvoljavali su proširenje do 180 kreveta. Kako je to bilo nedovoljno za brojnu gradsku sirotinju, a budući da su troškovi bolničkog kreveta iznosili oko 5.000 dinara godišnje odmah su počele da stižu donacije od bogatih građana. Među darodavcima bili su Fabrika Koste Ilića i sinova, supruga Vlade Ilića, beogradski slobodni zidari, trgovci Milan Srdanović i Dragojlo Obradović, dr Jovan Jovanović sa suprugom Katarinom, a takođe i ustanove, kao Opštinska štedionica, Narodna banka, Opšte jugoslovensko bankarsko društvo, Trgovačko industrijska banka, Francusko-srpska banka, Anglo-česka i praška banka, Jugoslovenski kreditni zavod. Gradski većnici priložili su po dve dnevnice, a svoj prilog je dao i Glavni birački odbor. Iznad svakog kreveta pisalo je ime darodavca. ${ }^{39}$

${ }^{37}$ IAB, fond OGB, fasc. 2134, Zadužbina N. Spasića - Poglavarstvu grada Beograda, 17. novembar 1936; IAB, fond OGB, fasc. 2134, Zadužbina N. Spasića - Gradskom poglavarstvu, 3. decembar 1936.

${ }^{38}$ IAB, fond OGB, fasc. 2134, predlog gradonačelnika Vlade Ilića Gradskom veću, 27. februar 1937; IAB, fond OGB, fasc. 2134, Gradsko veće 26. marta 1937. izveštava Finansijsko odeljenje da je na sednici od 15. marta 1937. usvojilo predlog predsednika.

${ }^{39}$ Milan Srdanović, trgovac, priložio je 20.000 dinara za nabavku četiri kreveta, fabrika Koste Ilića i sinova priložila je dva kreveta, supruga Vlade Ilića 10.000 dinara a slobodni zidari 15.000 dinara (Gradska bolnica na Bulbuderu, BON, 5, 1935, 334-335). U govoru prilikom svečanog otvaranja Vlada Ilić je rekao kako su novac priložili Opštinska štedionica (100.000 dinara), trgovac Miloš Srdanović (22.000), Narodna banka (20.000), beogradski slobodni zidari (15.000), supruga Vlade Ilića (10.000), Kosta Ilić i sinovi (10.000), dr Jovan Jovanović i gđa Katarina Jovanović (5.000), Opšte jugoslovensko bankarsko društvo (5000), Trgovačko-industrijska banka (5.000), Francusko-srpska banka (5.000), Anglo-česka i praš- 
Od posebnog je značaja bilo to što je bila namenjena prvenstveno siromašnim građanima, koji su tu imali pravo na besplatno lečenje. To se odnosilo na sve one sa uverenjem o siromašnom stanju, kao i na udovice sa troje i više dece slabog imovnog stanja, i na žitelje Beograda u trajanju od najmanje pet godina ako nisu bili u mogućnosti da plate. ${ }^{40}$ Opštinska uprava je donela Pravilnik Gradske bolnice u oktobru 1935, kojim su bili određeni troškovi i takse za lečenje. Korisnici su bili podeljeni u tri klase, od kojih je prva klasa plaćala 80 dinara, druga 40 a treća 25 dinara, sa dodatkom od $10 \%$ za intervencije i lekove. ${ }^{41}$ Bolnica je bila od najveće koristi onima koji nisu mogli da plate privatno lečenje, a za koje nije bilo mesta u državnim bolnicama. Međutim, po statistikama iz prve dve godine rada, lečeno je više bolesnika koji su mogli da plate nego siromašnih (3/4 platežnih bolesnika u odnosu na $1 / 4$ siromašnih). ${ }^{42}$

Tako je bolnica ostvarivala i prihod izvan budžeta. Međutim, ova pojava je verovatno tipična za početak rada svake nove ustanove, posebno one koja unosi neku inovaciju u dotadašnji rad. To ne umanjuje činjenicu da su njeni korisnici s vremenom sve više bili siromašni i građani srednjeg stanja. U početku bolnica je opsluživala samo Bulbuder, ali su vrlo brzo počeli da se javljaju pacijenti iz celog Beograda, pa i šire, iz drugih krajeva zemlje. ${ }^{43}$ Lekare i osoblje ove bolnice plaćala je opština, koja je inače finansirala njen kompletan rad (iz gradskog budžeta $u$ ove svrhe odvajano je 600.000 dinara, što je, na primer, $u$ to vreme bila cena jedne luksuzne vile $u$ Beogradu). ${ }^{44} \mathrm{Na}$ njeno čelo postavljen je dr Siniša Ilić, koji je vodio bolnicu i u vreme okupacije. ${ }^{45}$

ka banka (5.000), Jugoslovenski kreditni zavod (3.000), Dragojlo Obradović, trgovac (3.000), članovi Glavnog biračkog odbora (700) - Svečano otvaranje nove Gradske bolnice u Beogradu, BON, 9, 1935, 525-526.

${ }_{40}^{40}$ Juče je počela rad gradska bolnica, Politika, 2. decembar 1935.

${ }^{41}$ IAB, Zapisnici odbora opštine beogradske. Knjiga zapisnika odborskih odluka, knj. 1. 1933, inv. br. 67, Zapisnik XXVII sednice od 25. oktobra 1935; Juče je počela rad gradska bolnica, Politika, 2. decembar 1935.

${ }^{42}$ Zdravlje i socijalna pomoć...., 204-210.

${ }^{43}$ Isto; Gradska bolnica Beograd. 30 godina..., 5.

${ }^{44}$ IAB, Zapisnici odbora opštine beogradske. Knjiga zapisnika odborskih odluka, knj. 1. 1933, inv. br. 67, Zapisnik XXIII sednice od 30. avgusta 1935; Zdravlje i socijalna pomoć..., 204-210.

${ }^{45}$ Svečano otvaranje nove Gradske bolnice u Beogradu, BON, 9, 1935, 525-526. Prim. dr Siniša Ilić (Beograd 1897 - Beograd 1971). Povlačio se preko Albanije i položio maturu u Nici 1917. Studirao medicinu u Lionu i Monpeljeu. U Beogradu je radio u Opštoj državnoj bolnici gde je specijalizirao internu medicinu. Primarijus od 1934. Postavljen je za prvog upravnika i šefa Prvog internog odeljenja Gradske bolnice. Njegovom zaslugom nabavljeni su aparati za dijagnostiku - rentgen, EKG aparat, laboratorija i otvoreno je ginekološko-akušersko odeljenje u Sredačkoj ulici. On je i u toku okupacije bio na čelu bolnice. Formirao je prvo hirurško odeljenje 1943. Radio je kao lekar na Sremskom frontu, kao vojni 
Već u početku bolnica je bila jako opterećena. Za prvih 40 dana rada kroz nju je prošlo oko 120 bolesnika, a osećao se nedostatak posebnih odeljenja, kao i laboratorije i apoteke, prostorija i inventara. ${ }^{46} \mathrm{U}$ početku je bolnica imala samo dva interna odeljenja, ali je do početka Drugog svetskog rata veoma proširila svoje kapacitete: broj postelja je udvostručen (sa 100 na 200), otvoreni su ginekološko-akušersko i dispanzersko bolničko grudno odeljenje, pripojen je stacionar antituberkuloznog dispanzera sa 80 postelja, a 1941. otvoreno je i porođajno odeljenje sa 50 postelja. ${ }^{47} \mathrm{U}$ pogledu nabavke instrumenata i opreme stanje se brzo poboljšavalo - osnovan je bolnički fond koji je do početka rata iznosio 15 miliona dinara, deponovanih kod Opštinske štedionice. Iz tog fonda nabavljeni su prvi Simensov EKG i rentgen aparat, opremljena laboratorija i postojeća odeljenja, a kupljen je i prvi aparat za fluorografisanje, što je bilo od izuzetnog značaja za preventivno lečenje tuberkuloze. Godine 1940. otvoreno je rentgenološko odeljenje sa mogućnošću kompletnog snimanja. Laboratorija se značajnije razvila od 1936. godine. Do tog vremena se mogao raditi vrlo ograničen broj biohemijskih analiza, ali su tada nabavljeni mikroskop i centrifuga, pa lekari nisu više morali sami da vrše ove analize već je preuzet laborant iz Opšte državne bolnice. ${ }^{48}$ Tokom okupacije (1943) osnovani su hirurško odeljenje sa 40 postelja i urološki odsek, a porodilište je iz Krunske ulice, posle bombardovanja zgrade, preneto u zgradu Gradske bolnice. Posle savezničkog bombardovanja 1944, interno odeljenje je bilo pretvoreno u bolnicu za ranjenike. ${ }^{49}$

Otvaranje Gradske bolnice bio je vrlo značajan događaj u istoriji Beograda, posebno u pogledu modernizacije. Kao ustanova, ona je u to vreme predstavljala značajnu inovaciju u pristupu lečenju, koje je obuhvatalo kako kurativnu tako i preventivnu medicinu, što do tada nije bilo slučaj. ${ }^{50} \mathrm{U}$ bolnici su pacijenti mogli dobiti uputstva o daljem, kućnom lečenju, čime je ona vršila funkciju socijalnog staranja i higijenskog vaspitanja građana. Za to vreme moderna sredstva dijagnostike omogućavala su otkrivanje bolesti na vreme, a time i povećavala verovatnoću uspeha u lečenju. Iz ove bolnice su bolesnici, posle postavljanja dijagnoze, upućivani na dalje lečenje u odgovarajuće, najčešće državne zdravstvene ustanove. Za to vreme, ovo je bio

kardiolog u Vazduhoplovno-medicinskom institutu u Zemunu, penzionisan 1956. kao pukovnik. (Milan Andrejević, Stvarali su gradsku bolnicu..., 7).

${ }^{46}$ Dr Siniša Ilić, NJ. V. Kraljica Marija pregledala je novu Gradsku bolnicu, BON, 2, 1936, 160-164.

${ }^{47}$ Gradska bolnica Beograd. 30 godina..., 13, 45; Milan Andrejević, Stvarali su gradsku bolnicu.., 7

${ }^{48}$ Gradska bolnica Beograd. 30 godina..., 14-15, 57.

${ }^{49}$ Isto, 87, 159.

${ }^{50} \mathrm{Dr}$ M. Đ. Popović, Uloga gradskih bolnica u higijenskom vaspitanju građana, BON, 9, 1935, 522-524. 
revolucionarno novi pristup u lečenju. Kada je reč o njenom osnivanju i izgradnji, takođe su vidljivi neki bitni faktori modernizacije. S jedne strane, to su tada savremeni metodi gradnje i organizacije prostora u bolnici, a sa druge, to je nova bolnička zgrada kao pokretač komunalnog razvoja kraja u kojem je podignuta i, konačno, način njenog finansiranja koji takođe ukazuje na puteve modernizacije i razvoja srpskog društva tog vremena. To je, pre svega, saradnja privatne i opštinske inicijative u jednom značajnom poduhvatu. Pitanje zdravstva, socijalnog staranja i uopšte kvaliteta života širokih masa stanovništva pojavljuje se kao sasvim nova problematika u srpskom i jugoslovenskom društvu posle Prvog svetskog rata. Na to ukazuje i činjenica da je tada prvi put formirano državno ministarstvo za ove svrhe. Država ni izdaleka nije uspevala da odgovori svom zadatku na ovom planu, koji je svakako bio vrlo složen, tako da je ovaj prostor bio prepušten u velikoj meri privatnoj inicijativi. Izgradnja Gradske bolnice u Beogradu dobar je primer koliko je mogla biti delotvorna akcija zadužbinarstva i privatnog kapitala u vidu donacija. Sa druge strane, ovo je bio značajan korak i za beogradsku opštinu i njene komunalne službe, koje su bitno proširile svoje delovanje na polju zdravstva i socijalne zaštite. Takođe je važno i to što je bolnica bila širom otvorena ka siromašnim slojevima, ali je istovremeno uspevala da ostvari prihod i da rentabilno posluje, i pored toga što je delimično izdržavana iz gradskog budžeta. 
Ranka Gašić

THE FOUNDING OF BELGRADE CITY HOSPITAL IN 1935

\section{Summary}

After 1918 Beglrade's population grew quickly and in only five years its number was four times bigger than before the First World War. The city was mostly populated by poor peasants and workers-to-be, who lived in apalling conditions. Given that the health standards were low even before the war, this fact also contributed to the worsening of sanitary conditions in the city. Doctors, nurses and health institutions were scarce before the war, and it was only after 1918 that the Ministry for health and social issues was established in the new founded Kingdom of Serbs, Croats and Slovenes (later Yugoslavia). The General State Hospital in Belgrade could not meet the growing demand for health institutions, therefore, the City Council of Belgrade and the Nikola Spasić Foundation initiated in 1929 the founding of the Belgrade City Hospital. The building was erected in two years (1933-1935), and the opening ceremony was held in December 1935. The opening of this hospital was a significant moment in the modernization process in Belgrade. The building itself was built by then up-todate methods and building materials, the hospital was organized in a very advanced manner, and the fact that it was erected in a poor and desolate quarter of the city, contributed significantly to its urbanization (in terms of commodities such as water and sewage system, eletricity etc). Belgrade City Hospital was founded as a joint venture of city authorities and a private foundation (The Nikola Spasić Foundation), with the help of donations, but it was also able to work on the commercial basis and contribute to its own development. 